\title{
Coverage of employment protection legislation
}

Mariya Aleksynska* and Friederike Eberlein

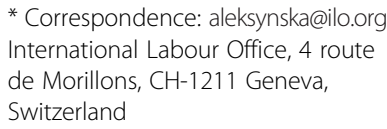

* Correspondence: aleksynska@ilo.org International Labour Office, 4 route de Morillons, CH-1211 Geneva, Switzerland

\begin{abstract}
This paper documents the construction of a novel database on coverage of workers by employment protection legislation (EPL), across over 90 countries around 2010. Coverage is shown to be an important, yet largely neglected, aspect of employment protection institution, complementing our knowledge about the protection level afforded by this institution. Our findings suggest that while coverage of employees across the world is generally high, coverage of all employed workers exhibits a substantial variation across countries in different regions and at different stages of development, reflecting the fact that wage employment still represents only a small proportion of total employment in developing countries. Our preliminary results indicate that there may not necessarily be a trade-off between the level of protection afforded by EPL and the proportion of workers legally covered by these rules. The results suggest that failure to account for EPL coverage in studies looking at aggregate effects of EPL level may lead to overestimating the importance of EPL, with this overestimation being especially large in lower-income countries.
\end{abstract}

JEL Classification: J5, J8

Keywords: Employment protection legislation, EPL, Coverage, Labor market institutions, Labor market indicators

\section{Introduction}

Employment protection legislation (EPL) is a key labor market institution. Over the past decades, the demand for knowledge and advice on the role and the adequate set of EPL has grown in the global context of heightened competition, pressure for greater labor market flexibility, and especially the jobs crisis of 2008-2016. Many countries adopted reforms of EPL in the hopes of boosting employment creation and reducing unemployment, especially among most vulnerable groups.

While the role of employment protection legislation has been studied in various contexts, EPL remains one of the most controversial labor market institutions, whether its impact is examined on unemployment, on productivity, or on economic growth (for most recent overviews, see Betcherman, 2012; 2014). One of the key features that virtually all studies on the role of EPL performed on the macroeconomic level share is the assumption that EPL applies to the whole labor market. Some authors do warn that labor markets in theory differ from other markets because different rules may govern employment of different workers (Boeri, 2011). Others also highlight that the existing measures of EPL account only for the legal dimension of this institution, such 
as the level of protection afforded to workers, but do not consider enforcement or coverage issues which are essential to understanding how labor regulations operate (Bertola et al., 2000). Yet, these issues remain largely out of the scope of the analysis. Empirical studies, starting from the pioneering Lazear (1990), to now typically cited Scarpetta (1996), Nickell (1997), Blanchard and Wolfers (2000), ${ }^{1}$ but also more recently Bassanini and Duval (2009) or De Serres et al. (2012), contain an implicit assumption that EPL rules apply to all workers. Likewise, some recent theoretical or general equilibrium studies, such as Bouis et al. (2011) or Cacciatore et al. (2012), model EPL effect similar to other macroeconomic variables that concern all workers. In the same spirit, analytical work conducted by international organizations, whether the World Bank (ex.: World Bank, 2013), the IMF (ex.: IMF, 2016), the OECD (ex.: OECD, 2007 and subsequent publications), or the ILO (ex.: ILO, 2015a), does not generally account for EPL coverage. Our paper shows that, because EPL rarely concerns all workers, such studies most probably overestimate the aggregate EPL effect, as well as the scope and the size of EPL reforms that need to be undertaken.

The aim of this paper is to document the extent to which the issue of EPL coverage may matter. We start by exploring the information provided by the ILO EPLex ${ }^{2}$ database, which records legal rules governing termination of employment contracts, ${ }^{3}$ regulations of fixed-term contracts, as well as the scope of regulation, or legal coverage. The ILO EPLex database, under its "scope of regulation" section, lists firm and worker categories that are formally excluded from statutes, in a sample of over 90 countries, over the period from 2009 to 2013. Equipped with this listing, we use national statistics of these countries, as well as other data sources, to assemble data on the number of workers in each of the excluded categories. We relate this to the total number of employees and of the employed to construct measures of legal coverage of employment protection legislation for employees and for the employed, respectively. As the ILO EPLex database contains legal coverage of workers concerned only by legal provisions and not including, apart from very few exceptions, case law or collective agreements on this subject, the coverage data that we thus assemble can be viewed as the EPL coverage by laws, or what can be called a general EPL regime, rather than EPL coverage at large. ${ }^{4}$ These coverage data also complement the EPLex aggregate indicators (ILO, 2015c) measuring the overall level of legal protection afforded to workers in case of individual termination of regular contracts at the initiative of the employer, as well as the ILO EPLex information on regulations of fixed-term contracts. This paper further documents all the methodological issues encountered during this data compilation, as well as all data sources and assumptions made. It also shows differences across countries in the extent of EPL legal coverage, highlighting the importance of accounting for it in the macroeconomic analysis of EPL.

Our results demonstrate that EPL coverage varies significantly across countries. In some countries, legal coverage of employees by the general EPL regime is complete (i.e., Armenia or Romania), while in others, it is relatively low (i.e., Turkey, which excludes domestic workers, agricultural workers, managers/executives, some other worker categories, but also enterprises with less than 30 workers). Naturally, because by definition EPL only applies to workers who are in a subordinate employment relationship (wage employees), and does not apply to self-employed, by construction, EPL coverage for employees is always higher than EPL coverage of the employed. In 
developed countries, where wage employment represents a large share of total employment, EPL coverage of the employed is close to that of employees, and both tend to be very high, ranging from 90 to $100 \%$. In developing countries, however, where wage employment remains limited, EPL concerns only a very small portion of all employed, being less than $5 \%$ in a country like Niger. Clearly, studies and policy actions addressing the role of EPL in such settings should focus not only on setting up an appropriate level of EPL but also on ensuring that EPL is a relevant institution.

The rest of the paper is structured as follows. Section 2 discusses some of the particularities of coverage information. Section 3 outlines methodological assumptions of the data construction. Section 4 provides detailed data description. Section 5 discusses the relationship between coverage and level of protection afforded by EPL. The remainder of the paper contains data collection assumptions (Appendices 1 and 2). All data sources are made available through an online appendix and are also available on request.

\section{Defining coverage: from legal to statistical definitions}

Legal EPL coverage can be defined as categories of workers and firms that are concerned by EPL provisions. Usually, legal statutes describing EPL rules stipulate its scope; in other words, they list groups of workers and enterprises that are (not) concerned by these provisions. We start by exploring the information provided by the ILO EPLex database, which records both legal rules governing termination of employment contracts and the scope of regulation, or legal coverage. Based on this information, Table 1 shows various categories of workers that may be excluded from EPL provisions. Only very few countries do not have any exclusions, suggesting that the coverage of employees is complete (Afghanistan, Armenia, Georgia, Malaysia, Republic of Moldova, Montenegro, Romania, and Serbia); however, in the vast majority of countries, at least some exclusions are present. Table 2 further shows various categories of firms that also may be excluded from EPL provisions. Usually, such exclusions are linked to the firm size. Only five countries of the sample fully exclude certain firms from legal coverage of employment protection legislation in case of individual dismissals, though a few others may also contain exclusions for cases of collective dismissals.

In its turn, statistical definition of legal EPL coverage can be formulated as a proportion of workers that are concerned by EPL provisions, either because they are directly covered or because they work in firms that are covered by legal EPL provisions.

In order to build statistical indicators of coverage, we collect data from various sources on (1) the number of individuals in each category of workers excluded from EPL provisions (based on Table 1); (2) the number of wage employees employed by firms that are excluded from legal provisions (based on Table 2); (3) total number of employees in an economy; and (4) total number of employed.

Using this information, two types of coverage are defined and computed as follows:

$$
\begin{aligned}
& \text { Coverage of employees }=(\text { Employees }- \text { excluded employees }) / \text { Employees } \\
& \text { Coverage of employed }=(\text { Employees }- \text { excluded employees }) / \text { Employed }
\end{aligned}
$$

By definition, employees constitute part of the employed in an economy. What we are looking for is to count how many wage employees are covered by EPL, how many are 
Table 1 Legal coverage, or scope of the general EPL regime: excluded workers

\begin{tabular}{|c|c|}
\hline None & Afghanistan, Armenia, Georgia, Malaysia, Republic of Moldova, Montenegro, Romania, Serbia \\
\hline Domestic workers & $\begin{array}{l}\text { Argentina a , Austria, Bangladesh, Brazil, Cambodia, Chile, Denmark, Egypt, Greece, Indonesia, } \\
\text { Italy, Jordan, Republic of Korea, Morocco, the Netherlands, Saudi Arabia, Singapore, Sweden, } \\
\text { Syrian Arab Republic, Tunisia, Turkey, United Arab Emirates, USA, Venezuela, Yemen, Zambia }\end{array}$ \\
\hline Judiciary & $\begin{array}{l}\text { Algeria, Azerbaijan, Bulgaria, Burkina Faso, Cambodia, Cameroon, Central African } \\
\text { Republic, Democratic Republic of the Congo, Czech Republic, Ethiopia, France, Hungary, } \\
\text { Italy, Switzerland, Viet Nam, Yemen, Zambia }\end{array}$ \\
\hline Seafarers & $\begin{array}{l}\text { Bangladesh, Belgium, Cambodia, Denmark, Finland, Germany, Greece, Japan, FYR of } \\
\text { Macedonia, Madagascar, Morocco, Nigeria, Norway, Saudi Arabia, Senegal, Singapore, } \\
\text { Slovakia, South Africa, Tunisia, Turkey, UK }\end{array}$ \\
\hline State security corps & Ghana, Lesotho, Namibia, South Africa, United Arab Emirates, Venezuela, Yemen, Zambia \\
\hline Diplomats & Angola, Antigua and Barbuda, Yemen \\
\hline Mine workers & Morocco \\
\hline Clergy & Denmark, Netherlands \\
\hline $\begin{array}{l}\text { Members of political } \\
\text { organizations }\end{array}$ & Viet Nam \\
\hline UN employees & Angola, Antigua, and Barbuda \\
\hline $\begin{array}{l}\text { Civil/public servants } \\
\text { (69 countries) }\end{array}$ & $\begin{array}{l}\text { Algeria, Angola, Antigua and Barbuda, Argentina, Austria, Bangladesh, Belgium, Brazil, } \\
\text { Bulgaria, Burkina Faso, Cambodia, Cameroon, Chile, China, Comoros, Democratic Republic } \\
\text { of the Congo, Cyprus, Czech Republic, Côte d'Ivoire, Denmark, Egypt, El Salvador, Ethiopia, } \\
\text { Finland, France, Gabon, Central African Republic, Germany, Greece, Honduras, Hungary, } \\
\text { Indonesia, Islamic Republic of Iran, Italy, Japan, Jordan, Republic of Korea, Lesotho, } \\
\text { Luxembourg, Madagascar, Mexico, Mongolia, Morocco, Netherlands, Niger, Nigeria, } \\
\text { Norway, Panama, Peru, Philippines, Portugal, Rwanda, Saint Lucia, Senegal, Slovakia, } \\
\text { Slovenia, Spain, Sri Lanka, Switzerland, Syrian Arab Republic, Thailand, Tunisia, Turkey, } \\
\text { United Arab Emirates, USA, Venezuela, Viet Nam, United Republic of Tanzania, Yemen }\end{array}$ \\
\hline Police & $\begin{array}{l}\text { Antigua and Barbuda, Austria, Belgium, Bulgaria, Cambodia, Cameroon, Democratic } \\
\text { Republic of Congo, Cyprus, Czech Republic, Ethiopia, France, Ghana, Hungary, Italy, } \\
\text { Lesotho, Malawi, Namibia, Netherlands, Nigeria, Slovenia, Switzerland, United Republic } \\
\text { of Tanzania, United Arab Emirates, UK, Venezuela, Viet Nam, Zambia }\end{array}$ \\
\hline $\begin{array}{l}\text { Managerial/executive } \\
\text { positions }\end{array}$ & $\begin{array}{l}\text { Angola, Austria, Bangladesh, Canada, Chile, Estonia, Ethiopia, Germany, Italy, Kyrgyzstan, Nigeria, } \\
\text { Portugal, Russian Federation, Singapore, Slovenia, Sweden, Turkey, USA, Viet Nam, Zambia }\end{array}$ \\
\hline Sportsmen & Italy, Saudi Arabia, Turkey \\
\hline $\begin{array}{l}\text { Employers' family } \\
\text { members }\end{array}$ & $\begin{array}{l}\text { Angola, Bangladesh, Egypt, Islamic Republic of Iran, Jordan, Republic of Korea, Nigeria, } \\
\text { Saint Lucia, Saudi Arabia, Spain, Sweden, Syrian Arab Republic, Turkey, Uganda, Yemen }\end{array}$ \\
\hline Actors & Morocco, New Zealand \\
\hline $\begin{array}{l}\text { Auxiliary administrative } \\
\text { employees }\end{array}$ & Cameroon \\
\hline Teachers & Bangladesh, Belgium, Denmark, Greece, Netherlands \\
\hline Flying personnel & Cambodia, FYR of Macedonia, Nigeria, Turkey \\
\hline Agricultural workers & $\begin{array}{l}\text { Argentina }{ }^{a} \text {, Austria, Bangladesh, Brazil, Greece, Honduras, Jordan, Rwanda, Saudi Arabia, } \\
\text { Syrian Arab Republic, Thailand, Turkey, United Arab Emirates, USA, Yemen }\end{array}$ \\
\hline Army & $\begin{array}{l}\text { Algeria, Antigua and Barbuda, Austria, Azerbaijan, Belgium, Bulgaria, Burkina Faso, Cambodia, } \\
\text { Cameroon, Central African Republic, Democratic Republic of Congo, Cyprus, Czech Republic, } \\
\text { Ethiopia, France, Germany, Ghana, Hungary, Italy, Kyrgyzstan, Lesotho, Malawi, Namibia, } \\
\text { Netherlands, Nigeria, Norway, Russian Federation, Slovenia, South Africa, Switzerland, United } \\
\text { Republic of Tanzania, Uganda, United Arab Emirates, UK, Venezuela, Viet Nam, Yemen, Zambia }\end{array}$ \\
\hline $\begin{array}{l}\text { Members of } \\
\text { cooperatives }\end{array}$ & Angola, Greece, Panama, Sri Lanka, Viet Nam \\
\hline Prison personnel & Cameroon, Ghana, Lesotho, Malawi, Namibia, United Republic of Tanzania, Zambia \\
\hline Apprentices & Denmark, Lesotho, Morocco, Turkey, \\
\hline Journalists & Bangladesh, Italy, Morocco \\
\hline $\begin{array}{l}\text { Non-federally } \\
\text { regulated workers }\end{array}$ & Australia, Canada (Federal only) \\
\hline
\end{tabular}


Table 1 Legal coverage, or scope of the general EPL regime: excluded workers (Continued)

\begin{tabular}{ll}
\hline Dock workers & Belgium \\
Casual workers & Australia \\
Blue-collar workers & Denmark $^{\text {b }}$
\end{tabular}

${ }^{a}$ In Argentina, agricultural workers are included into the EPL coverage since 2012 and domestic workers since 2013 bIn Denmark, white-collar workers are covered by specific collective agreements Source: ILO (2015b)

not, and relating the former number to the number of wage employees and of the employed. Among employees, we include both permanent and temporary employees. This inclusion is deliberate: on the one hand, both permanent and temporary employees are generally covered by EPL rules; on the other hand, different costs associated with terminating permanent and temporary worker may impact the distribution of

Table 2 Legal coverage or scope of the general EPL regime: Excluded enterprises

\begin{tabular}{ll}
\hline Firm size Country \\
\hline none & Afghanistan, Algeria, Angola, Antigua and Barbuda, Argentina, Armenia, Azerbaijan, Bangladesh, Brazil, \\
& Burkina Faso, Cambodia, Cameroon, Canada (Federal only), Central African Republic, Chile, China, \\
& Comoros, Democratic Republic of the Congo, Côte d'Ivoire, Egypt, El Salvador, Estonia, Ethiopia, \\
& Gabon, Georgia, Ghana, Honduras, Indonesia, Islamic Republic of Iran, Japan, Jordan, Lesotho, \\
& Luxembourg, FYR of Macedonia, Madagascar, Malawi, Malaysia, Mexico, Republic of Moldova, \\
& $\begin{array}{l}\text { Mongolia, Namibia, Netherlands, New Zealand, Niger, Nigeria, Norway, Panama, Peru, Philippines, } \\
\text { Romania, Russian Federation, Rwanda, Saint Lucia, Saudi Arabia, Senegal, Singapore, South Africa, }\end{array}$ \\
& Spain, Sweden, Syrian Arab Republic, United Republic of Tanzania, Thailand, Tunisia, Uganda, United \\
& Arab Emirates, United Kingdom, Viet Nam, Yemen, Zambia \\
$\leq 5$ & Austria, Korea \\
$\leq 10$ & Germany \\
$\leq 15$ & Sri Lanka \\
$\leq 30$ & Turkey
\end{tabular}

Source: ILO (2015b)

Note:

Morocco, Belgium, Bulgaria, Cyprus, Czech Republic, Denmark, Greece, Hungary, Montenegro, Serbia, Slovakia, Slovenia, Switzerland - collective dismissal rules do not cover all enterprises (exceptions exist by enterprise size), but individual dismissal rules apply to all enterprises

Portugal, Venezuela, Australia, and Italy - have different rules for enterprises of different size (as recorded in EPLex indicators, which are computed separately for each broad category of enterprises); though all enterprises are covered by EPL provisions

France - there is no general exclusion based on the size of the enterprise. However, the LC provides for exemptions from some procedural requirement for enterprises employing less than 11 workers in particular with respect to sanctions in the event of non compliance with dismissal (procedural and substantive)requirements. See art. L. 1235-5 LC and art. L. 1235-14 LC (on economic dismissal)

United States of America - there is no federal law regulating the termination of employment as such. The United States has an "at will" employment system which allows for the dismissal of workers for any reason, or for no reason at all. With the exceptions of the State of Montana, the Commonwealth of Puerto Rico, and the non-metropolitan territory of the US Virgin Islands, there is currently no legislation specifically focused on employment termination. Some of the laws, as reflected in EPLex indicators, are federal anti discrimination laws which operate to provide some measure of protection to employees in regard to termination; they are supplemented in many of the fifty states by similar legislation There are no exclusions in the National Labor Relations Act of 1935, as amended through April 18, 1990, 29 U.S.C. secs. 151-169; in Occupational Health and Safety Act of 1970, as amended through January 2004, 29 U.S.C. secs. 651-678; or in The Jury System Improvements Act of, Pub. L. 95-572, as amended by Public Law 110-406 of 13 October 2008, 28 U.S.C. sec. 1861 et seq.. Note, however, the following:

- Title VII of the Civil Rights Act: covers only employers having 15 or more employees (42 U.S.C. sec. 2000e(b) [sec. 701]).

- The Age Discrimination in Employment Act: covers only employers having 20 or more employees (29 U.S.C. sec. 630 (b) [sec. 11]).

- The Americans with Disabilities Act: covers only employers having 15 or more employees (42 U.S.C. sec. 12111(5)(A)

[sec. 101]).

- The Genetic Information Nondiscrimination Act of 2008: covers only employers having 15 or more employees ([sec. 201]), referring to sec. $701 \mathrm{~b}$ of the CRA (42 U.S.C.A. $\S 2000 \mathrm{e}(\mathrm{b})$ ). The Family and Medical Leave Act of 1993: covers only employers having 50 or more employees ([sec. 101]

- The Worker Adjustment and Retraining Notification Act: covers only employers with 100 or more employees, not counting employees who have worked less than 6 months in the last 12 months and not counting employees who work an average of less than 20 hours a week (42 U.S.C. sec. 2101).

Moreover, some of these laws also include worker-related exclusions, such as for example worker tenure or accumulated hours of work

Thus, in the US, different workers in enterprises of different size may be covered by different provisions 
workers across the permanent-temporary divide, and we certainly do not wish to embed this endogeneity into coverage indicators. ${ }^{5}$ Note that, as per international statistical definitions (Appendix 2), contributing family members and members of producer's cooperatives constitute employed individuals, but not employees; therefore, when such categories of workers are explicitly mentioned in national EPL as excluded groups, we ignore them for the computation of coverage.

As the ILO EPLex database contains data annually between 2009 and 2013, we attempted to collect data for the same time period, annually. However, annual data availability for many developing countries remains a challenge, and for this reason, in the current paper, we report the results based on data only for the year 2010-the year with the most comparable data-or the latest available year if neither data for 2010 nor for the whole 2009-2013 range are available. As changes in legal coverage caused by changes in legislation are rare, the statistical coverage exhibits low variation over time and is in any case quite similar within countries across the years of the same decade. The variations that we uncovered in the 2009-2013 period reflect mainly changes in employment levels, the fact that entry to and exit from employment may differ between specific excluded groups and an economy as a whole, as well as some changes in the structure of employment, i.e., movement towards greater proportion of wage employment in developing countries. However, to the extent that one can accept the assumption that flows in and out of aggregate employment are proportional to flows in and out those occupations and sectors that are excluded from regulations, and that changes in the structure of employment occur at a slow pace, such variations can be considered as marginal.

\section{Data description}

The obtained data are the first of its kind and do offer some novel insights on the potential role of employment protection. Figure 1 shows the distribution of the two types of coverage-coverage of employees and coverage of employed. Table 3 also displays descriptive statistics. Jointly, they show that coverage of employees is usually quite high in all considered countries, with the median of $99 \%$, though some important outliers are present. Among such outliers are Bangladesh, United Arab Emirates, and Turkey, which feature the lowest legal coverage of employees, because by law, very sizeable groups of workers, such as agricultural and domestic workers, are excluded from employment protection. In Turkey, also a sizeable group of employees is excluded because firms with less than 30 workers are not covered by the EPL provisions. In half of countries of our sample, however, legal coverage of wage employees is complete (Figs. 1 and 2).

The differences in coverage of employees across countries primarily reflect the differences in legal settings (i.e., how many groups of workers, and which specific groups, will be excluded in one country but not in another), as well the sizes of excluded groups that vary across countries. Thus, for example, domestic workers are excluded from employment protection in both Denmark and Saudi Arabia; however, in relative terms, there are over ten times more domestic workers in Saudi Arabia than in Denmark, thus driving a wedge between coverage of employees in these two countries. 


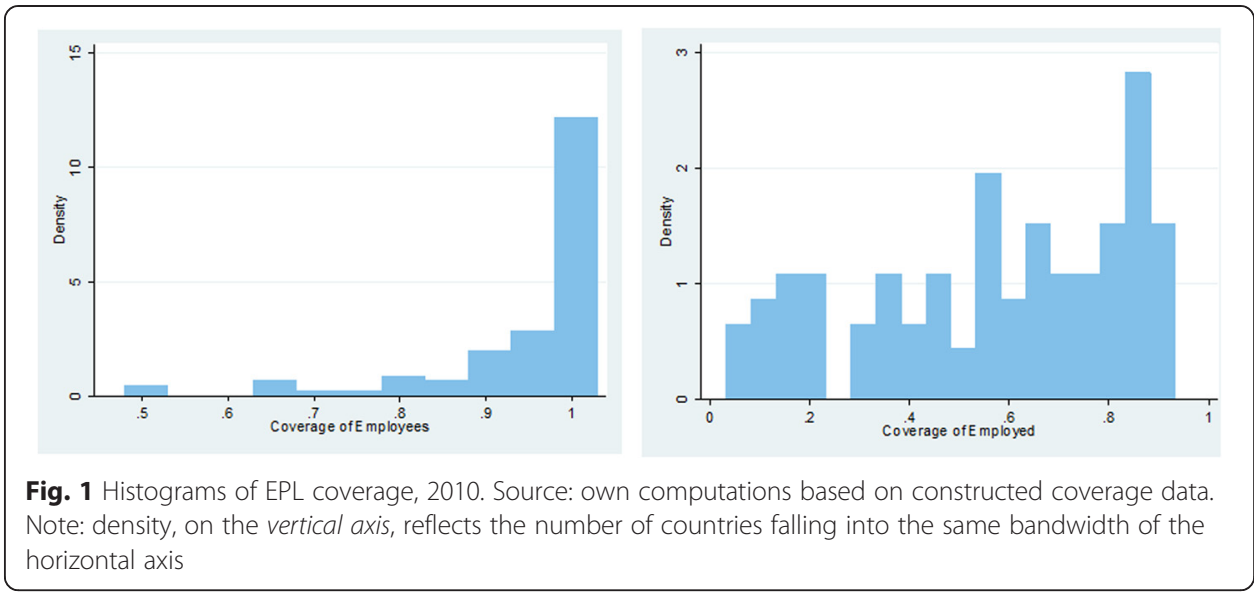

Coverage of employed, by definition, is lower than coverage of employees. The differences between two types of coverage reflect mainly the structure of employment. While in developed countries, the share of wage employment in total employment is high, it can still be as low as $20 \%$ in developing countries, as self-employment remains sizeable. Given this, coverage of employed also exhibits a substantially higher variability across countries (Figs. 1 and 3). Because, by definition, EPL applies only to workers in a subordinate employment relationship, coverage of employed can never reach $100 \%$, and in the majority of countries, it ranges from 40 to $70 \%$. The lowest coverage is recorded in Niger, with less than $5 \%$ of employed being legally covered by EPL.

Consequently, differences across these two coverage variables primarily reflect developmental differences and regional disparities, to the extent that the latter are linked to development (Figs. 4 and 5). As countries progress in their development, coverage of employed increases and also approaches that of the employees.

Interestingly, coverage of employees can be equally high in developed and developing countries, and we also find examples of both high and low coverage of employees at all stages of development and in all regions. For example, among low-income countries, the lowest coverage of employees is found in Rwanda (less than $70 \%$ ), but ten out of 17 countries in this income group feature a complete coverage of employees. Among high-income countries, the lowest coverage of employees is in the United Arab Emirates (around $50 \%$ ), Australia and Korea (slightly less than $70 \%$ ), while nine out of 24 countries in this income group feature a complete coverage of employees of $100 \%$. This may suggest that not only levels of development but also specific legal or political economy preferences may be at work in coverage design. In contrast, coverage of the employed clearly increases with the level of development. It is also the highest in European countries, though some exceptions are also present, as coverage of employed is quite low in Germany and Austria.

Table 3 Descriptive Statistics of EPL Coverage, 2010

\begin{tabular}{lllllll}
\hline Variable & N Obs & Mean & Median & Std. Dev. & Min & Max \\
\hline Coverage of employees & 93 & 0,94 & 0,99 & 0,11 & 0,48 & 1,00 \\
Coverage of employed & 93 & 0,57 & 0,62 & 0,26 & 0,03 & 0,92 \\
\hline
\end{tabular}

Source: own computations based on constructed coverage data 


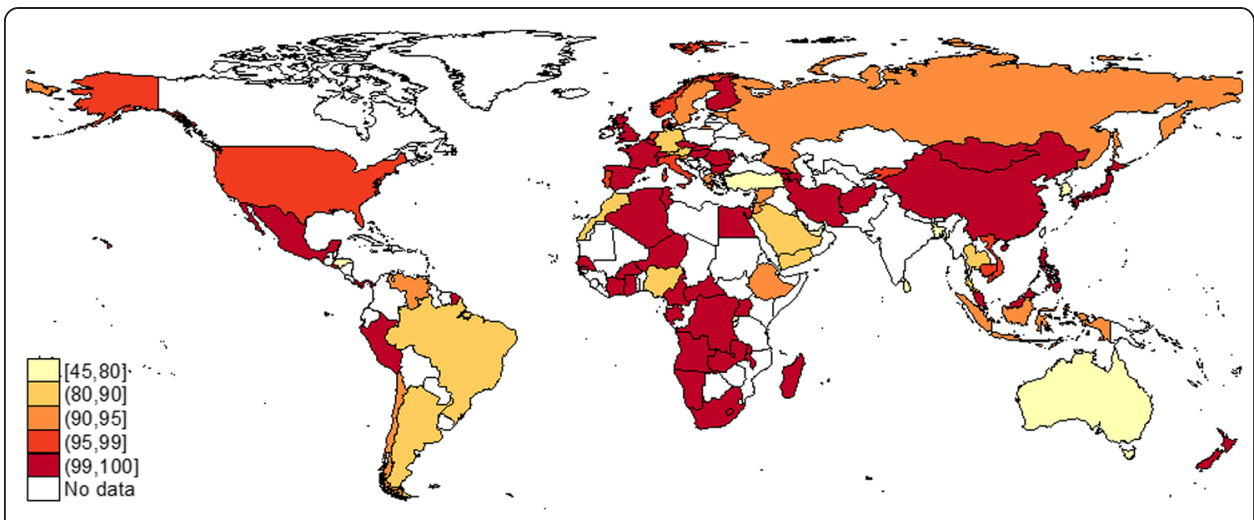

Fig. 2 World map of EPL coverage of employees, 2010. Source: own computations based on constructed coverage data

Figure 6 provides some further specific examples, for a subset of the world's major (G-20) economies. It shows a variation in coverage of employed in a range from 38 to $90 \%$. It also shows that both types of coverage do not necessarily move together. For example, while in Korea and Turkey both types of coverage are relatively low, in Indonesia, coverage of employees is high, but the coverage of employed is the lowest of the G-20 subsample.

Over the considered period of time, only two countries with legal reforms of coverage were found: Argentina and Hungary. Argentina expanded considerably its scope of EPL regulations, by including agricultural workers in 2012 and domestic workers in 2013. EPL coverage of employed in this country thus passed from about $50 \%$ in 2011, to $53 \%$ in 2012, to 58 \% in 2013 (Fig. 7). In Hungary, civil/public workers were excluded from the general EPL regime before 2012 and governed by a separate act; the New Labour Code which came into force in 2012 does not include this provision. However, to the extent that civil/public workers were and are covered by separate provisions, the new rule did not affect the overall coverage computation.

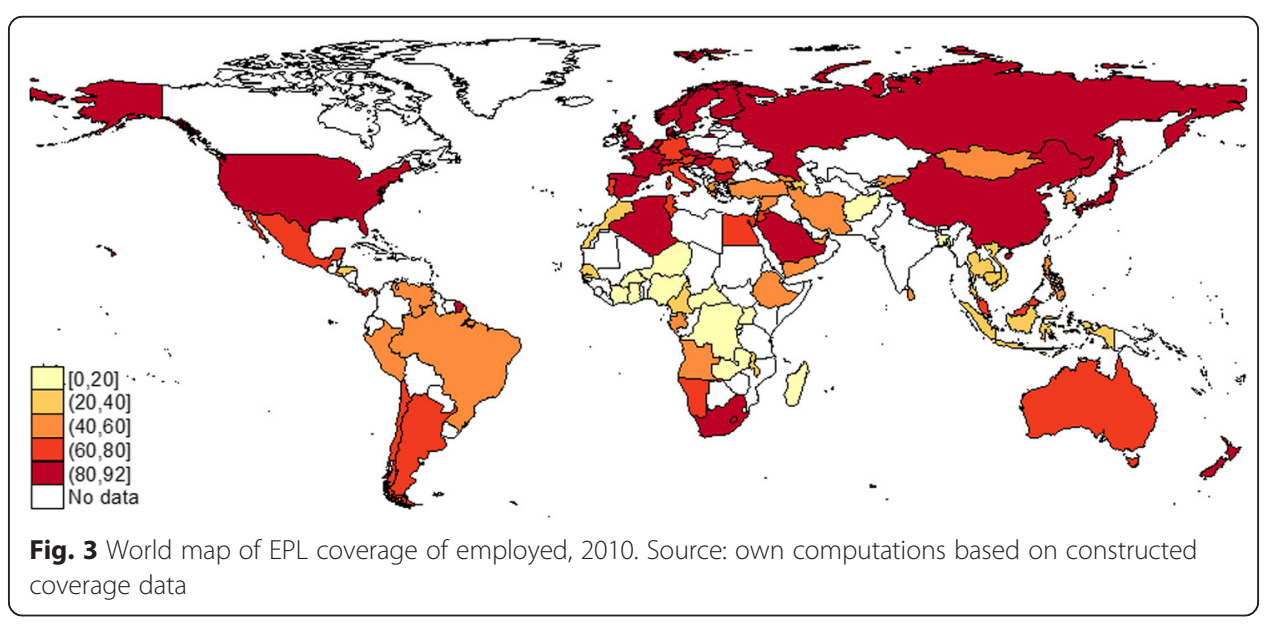




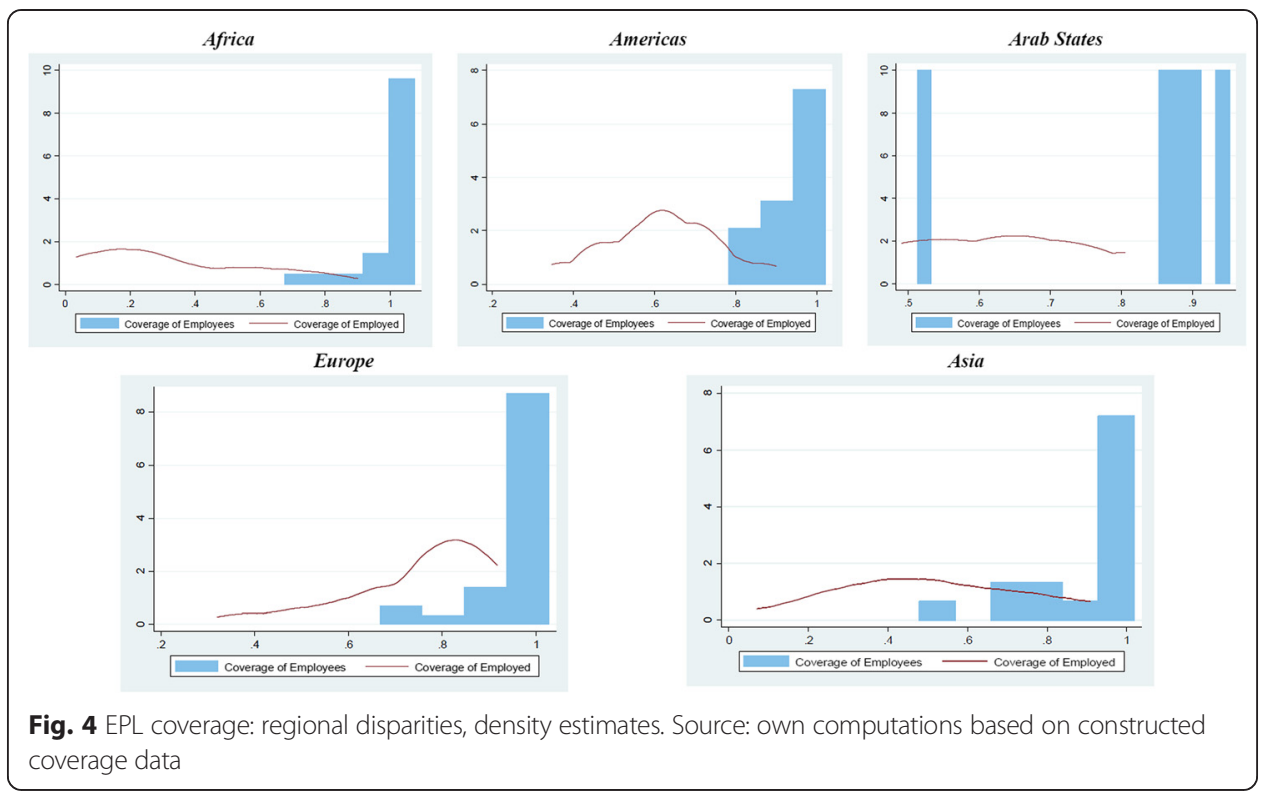

\section{Coverage: some particularities}

Obtained indicators of EPL coverage have several particularities, and it is important to keep them in mind when using these coverage data. The first particularity is that, while some workers are excluded from the general EPL regime, this does not necessarily mean that they are unprotected. In fact, for some of them, special regimes may apply, which may be less, or more, advantageous, as compared to the general regime. A typical example would be public service, which in many countries would offer more advantageous employment protection to workers as compared to workers in private sector. The opposite situation is observed for domestic workers, who in the vast

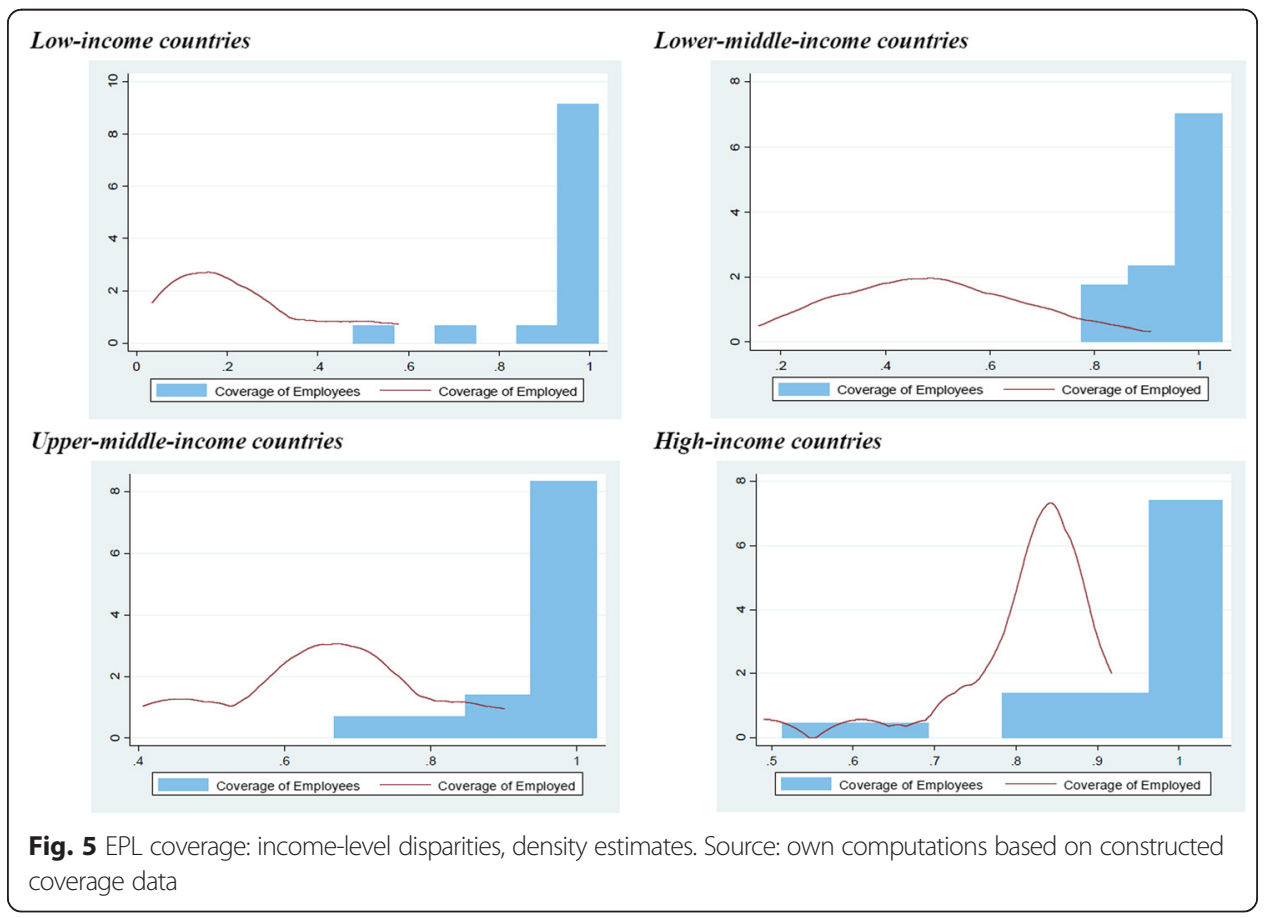




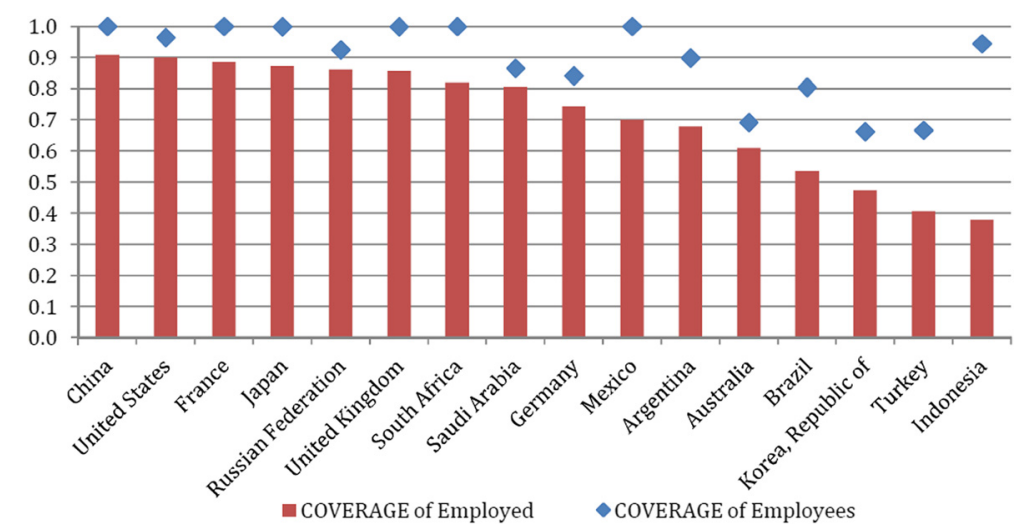

Fig. 6 Some country-specific examples (countries of G-20 subsample). Source: own computations based on constructed coverage data

majority of cases not only are unprotected by the general EPL regime but also do not enjoy any protection whatsoever. In constructing statistical data on coverage, we assumed that worker categories such as civil and public servants, judges, teachers, or policemen enjoy an EPL regime at least as protective as the general EPL regime that applies to other workers. For other worker categories, such as domestic workers, we generally accepted that they genuinely fall out of scope of the EPL protection. Appendix 1 contains the full list of possible excluded categories, as prescribed by national practice, as well as the explanation of how they were treated for the purposes of collecting statistical coverage information. It is important to bear in mind this unavoidable asymmetry of treatment of some of the excluded groups across (and even within) countries.

Second, in this project, we focused on coverage of workers by general provisions contained in national laws and, with some exceptions, national collective agreements. Needless to say, case law, collective agreements at industry, sector, or plant level, may contain provisions for those workers that have fallen out of scope of the national law and may also be less, or more, generous, than the general EPL regime. Moreover, in some countries, individual labor contracts may contain provisions that are more generous than those offered by national law. Therefore, we understand by obtained coverage the coverage of the general EPL regime and not of the overall EPL regime. Indeed, to have a complete picture of EPL in a country, it would be necessary to collect data not

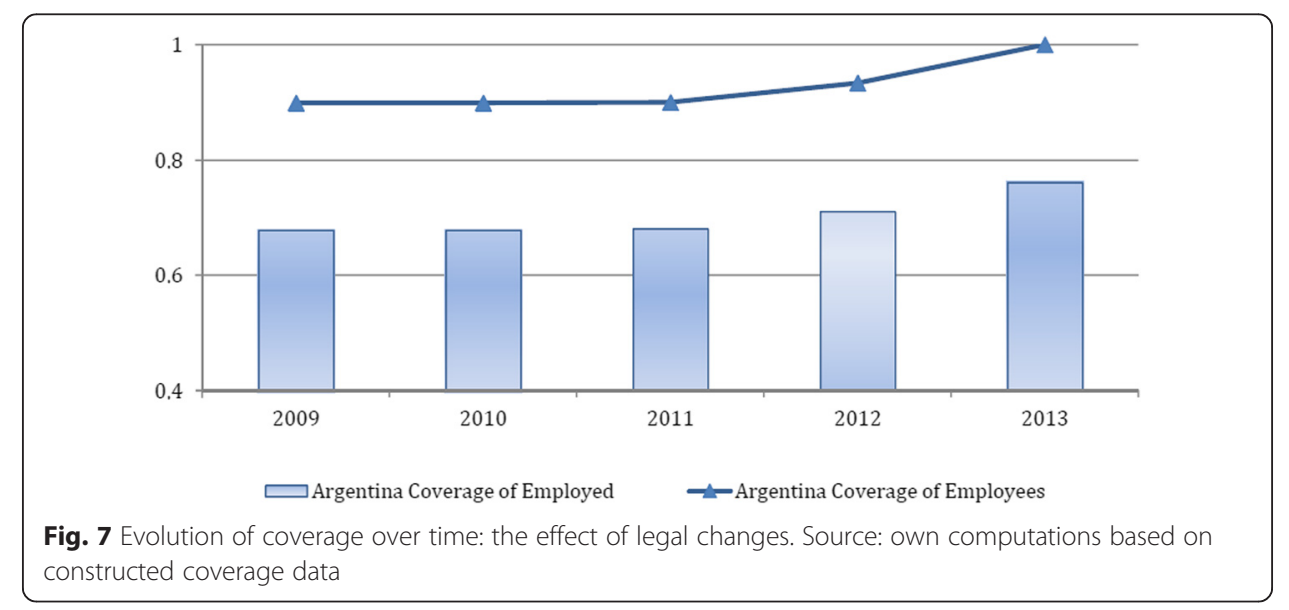


only on general EPL rules as stated in the labor laws but also on all special regimes and special cases, and complement this information with the number of individuals in each of the special-regime categories-an exercise beyond the scope of this paper.

Another particularity of coverage is that some firms or workers may be fully excluded from all provisions of the general EPL regime, while others may be excluded only from some provisions. For example, in the USA, over a dozen of national acts contain some aspects of EPL provisions, but they apply to different workers or firms. For example, the Family and Medical Leave Act, which contains provisions regarding parental leave and discharge of employees for opposing any practice made unlawful by the Act, covers only enterprises with 50 employees or more, as well as employees of such enterprises provided they have worked for the employer for at least 12 months. In comparison, the Age Discrimination in Employment Act, prohibiting the discharge on the grounds of age, covers only employers having 20 or more employees. Thus, some employees would enjoy the provisions of Age Discrimination in Employment Act, but not of the Family and Medical Leave Act. Yet, some other acts may contain exclusions for firms of lower size; in addition, in case of mass layoffs, higher firm-size thresholds may apply. Another example is France, where there is no general exclusion based on the size of the enterprise, but the Labour Code provides for exemptions from some procedural requirements for enterprises employing less than 11 workers in particular with respect to sanctions in the event of non-compliance with dismissal.

Relatedly, there is an important distinction between coverage and between different provisions for different groups of workers. For example, in Austria, Belgium, or Greece, different EPL rules exist for blue-collar and for white-collar workers. Similarly, in the Democratic Republic of the Congo, Côte d'Ivoire, and Madagascar, workers are divided into categories, and different EPL rules (such as notice periods or severance pay) apply to workers in each category. Another example is Senegal and Tunisia, where workers in managerial positions enjoy levels of protection different from those of other workers. In all of these cases, each of the specific categories is considered as being covered by EPL, despite the fact that different rules may apply.

There are two implications of these methodological issues. First, in constructing statistical coverage data, to the extent possible, we accounted only for those workers that are excluded from all legal EPL provisions. This means that our coverage data contain workers with heterogeneous degree of protection. For example, in the USA, coverage data would include workers that fall under some, though not all, acts and thus may be protected in different ways. Second, in many countries, the obtained coverage data are relatively high because they reflect the minimum possible level of afforded legal protection to the largest possible base of workers. In other words, it represents an upper bound of the most basic EPL protection afforded to workers.

\section{Legal coverage of protection and level of protection: are there trade-offs?}

Coverage of employment protection is a specific aspect of this institution, determining, together with the level of protection afforded by the institution and also together with compliance, the degree to which this institution actually matters. Some observers, however, may be concerned that coverage and level of protection necessarily embed tradeoffs: high levels of protection cannot be afforded to all, while relatively low levels of protection can be granted to a larger group of workers more easily (Boeri and Van 
Ours, 2008). In this section, we touch-base on this issue, by exploring, in a descriptive manner, whether such arbitrage is actually observed.

In Table 4 (panel A), we correlate two types of coverage with the levels of protection afforded to workers on permanent contracts, when those are terminated at the initiative of the employer. This level is captured by a composite ILO EPLex indicator, which embeds information on trial periods, substantial requirements for dismissals (valid and prohibited grounds), notification procedures and the duration of notice periods, and severance and redundancy pay, as well as remedies available in case of contesting a dismissal. This indicator is constructed for the same sample of countries as our coverage data (ILO, 2015c). As we can see, correlations between both types of coverage and EPLex indicator are small but non-negligible, though, if anything, they are positive. Figure 8 plots the EPL level against coverage of employed for the full sample of countries, showing also graphically that the relationship is positive.

In Table 4 (panels A and B), we provide such correlations separately for lowerincome and higher-income countries. Interestingly, lower-income countries feature higher degree of correlation between EPL level and EPL coverage than higher-income countries, and this correlation is particularly high for the coverage of employed. One explanation-which however would warrant a deeper investigation-would be that, for these two subsets of countries, two opposing processes are at work.

To the extent that coverage of employed is closely associated with country's level of development, countries with higher level of protection afforded by EPL also seem to be the ones with higher levels of development and coverage. In lower-income countries, this result is consistent with the "structural transformation" models which imply that the growth process produces higher protection afforded by labor law (Deakin, 2015). Some of these countries have also adopted EPL institution relatively recently as part of their development, and higher levels of protection serve important developmental functions (Deakin, 2014). In higher-income countries, ${ }^{6}$ however, positive correlation may be attenuated by the fact that some of these countries witnessed

Table 4 Correlation between EPL Level and coverage

\begin{tabular}{|c|c|c|c|}
\hline \multicolumn{4}{|l|}{ A. All countries } \\
\hline & EPLex & Coverage of employees & Coverage of employed \\
\hline EPLex & 1.00 & & \\
\hline Coverage of employees & 0.19 & 1.00 & \\
\hline Coverage of employed & 0.10 & 0.24 & 1.00 \\
\hline \multicolumn{4}{|c|}{ B. Low-income and lower-middle-income countries } \\
\hline & EPLex & Coverage of employees & Coverage of employed \\
\hline EPLex & 1.00 & & \\
\hline Coverage of employees & 0.26 & 1.00 & \\
\hline Coverage of employed & 0.38 & 0.21 & 1.00 \\
\hline \multicolumn{4}{|c|}{ C. Higher-middle-income and higher-income countries } \\
\hline & EPLex & Coverage of employees & Coverage of employed \\
\hline EPLex & 1.00 & & \\
\hline Coverage of employees & 0.11 & 1.00 & \\
\hline Coverage of employed & 0.17 & 0.55 & 1.00 \\
\hline
\end{tabular}

Source: own computations based on constructed coverage data and ILO EPLex (2015c) 


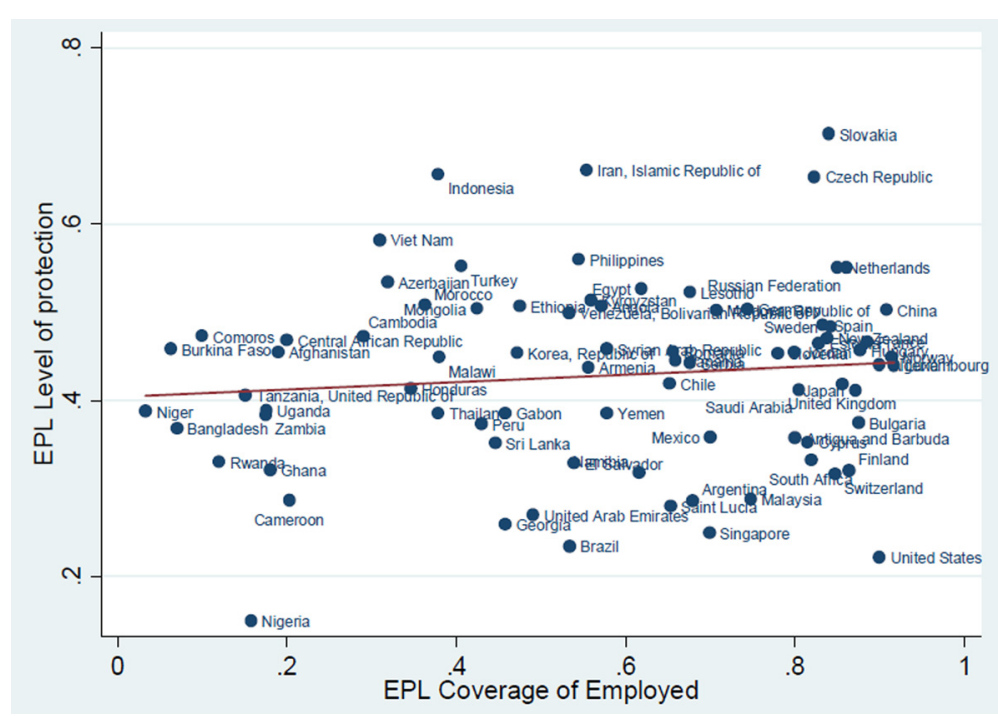

Fig. 8 EPL level and coverage: are there trade-offs? Source: own computations based on constructed coverage data and IIO EPLex (2015)

at least a century-long history of EPL, during which the EPL level has both gone up and down (Adams and Deakin, 2014; Aleksynska and Schmidt, 2014), with substantially more deregulation in the past years promulgated by the Washington Consensus (Deakin, 2015). The result observed for 2010 in these countries may thus be an outcome of a longer process whereby higher shares of covered workers were confronted with a recent decline in the protection levels.

As the coverage data that we collected concerns not only regulations of permanent contracts but also of fixed-term contracts, we also correlate two types of coverage with the ILO EPL dummy variable measuring whether fixed-term contracts are regulated or not (in other words, whether the laws set any limits on the reasons for such contracts use, their maximum duration, or the number of renewals). The correlation results are very similar to the ones above (Table 5): positive correlations between coverage and levels of protection are observed, with higher correlations for lower-income countries and almost no correlation for higher-income ones.

Overall, these results indicate that rather than being a substitute for the degree of protection, legal coverage represents yet another pillar of the employment protection legislation that co-exists with the protection's level. Because correlation between EPL level and coverage can be non-negligible, our results suggest that failure to account for EPL coverage in studies looking at aggregate effects of EPL level may lead to overestimation of the role of EPL, and this overestimation may be especially important for lower-income countries. Conversely, extending results of empirical findings on the role of EPL based on developed-countries samples to developing countries should be done with great caution.

\section{From legal to effective coverage}

One last point about collected data warranting a discussion concerns the fact that these data represent legal, or de jure, but not effective, or de facto, coverage. To compute the effective EPL coverage, several additional aspects need to be taken into account. 
Table 5 Correlation between regulation of FTC and coverage

\begin{tabular}{|c|c|c|c|}
\hline \multicolumn{4}{|l|}{ A. All countries } \\
\hline & EPLex & Coverage of employees & Coverage of employed \\
\hline FTC are regulated & \multicolumn{3}{|l|}{1.00} \\
\hline Coverage of employees & 0.13 & 1.00 & \\
\hline Coverage of employed & 0.10 & 0.19 & 1.00 \\
\hline \multicolumn{4}{|c|}{ B. Low-income and lower-middle-income countries } \\
\hline & EPLex & Coverage of employees & Coverage of employed \\
\hline FTC are regulated & \multicolumn{3}{|l|}{1.00} \\
\hline Coverage of employees & 0.28 & 1.00 & \\
\hline Coverage of employed & 0.16 & 0.22 & 1.00 \\
\hline \multicolumn{4}{|c|}{ C. Higher-middle-income and higher-income countries } \\
\hline & EPLex & Coverage of employees & Coverage of employed \\
\hline FTC are regulated & \multicolumn{3}{|l|}{1.00} \\
\hline Coverage of employees & -0.01 & 1.00 & \\
\hline Coverage of employed & 0.04 & 0.56 & 1.00 \\
\hline
\end{tabular}

Source: own computations based on constructed coverage data and IIO (2015b)

First, employment protection legislation is a set of rules that govern (a) termination of regular contracts, in case of individual and collective dismissals, and (b) hiring of employees on fixed-term contracts. The legal coverage data that we collected concern both types of regulations, and hence both types of workers-regular wage employees and wage employees holding fixed-term contracts. However, in many developing countries, but also recently in developed countries as well, total wage employment is not exhaustively measured as a sum of regular and fixed-term employees, and other categories, such as casual workers, additionally exist. According to the 1993 Resolution concerning the International Classification of Status in Employment, ${ }^{7}$ casual workers are defined as persons "who have an explicit or implicit contract of employment which is not expected to continue for more than a short period, whose duration is to be determined by national circumstance." As shown by De Stefano (2016), in the majority of countries, these workers are totally or partially excluded from labor protection, either de jure, or de facto. One country that particularly stands out in this regard is Australia. In this country, casual workers are explicitly excluded by law from EPL provisions. We thus also excluded them from computation of de jure coverage. In other countries, as shown by De Stefano (2016), the law is less clear cut and may exclude casual workers from some of the provisions or contain special provisions for them. Thus, we do not exclude casual workers from computing de jure coverage in all other countries, though de facto, they are likely to be excluded.

According to the ILO (2016, forthcoming), casual workers represent nearly a quarter of wage employees in Indonesia and Bangladesh and about $14 \%$ in Uganda. If all of these workers are excluded from computation of coverage, effective, or de facto, coverage of employees would drop to about $70 \%$ in Indonesia (in contrast with computed $94.5 \%$ legal coverage of employees), to about $24 \%$ in Bangladesh (in contrast with currently computed $48 \%$ legal coverage of 
employees), and to about $86 \%$ in Uganda (in contrast with currently computed $100 \%$ legal coverage of employees).

Unfortunately, scaling up these computations to all countries is not possible, because data on casual workers is not available in all countries. Such data can also be quite volatile, to the extent that casual employees represent a margin of adjustment for employers (ibid). However, it is important to bear in mind that the size of the casual work phenomenon can be important and that the role of EPL in countries with sizeable casual work would be further overestimated. The effective coverage of employees computed by excluding casual workers would also be considerably more endogenous to the level of EPL, in contrast to the legal coverage, because recourse to casual work may be propelled by motivations to avoid complying with EPL. Similarly, new forms of employment, such as crowd-work through internet platforms (when classified as wage employment), disguised selfemployment, ambiguous employment relationships, or other forms, may arise to avoid EPL and lead to a decrease in effective EPL coverage.

Another issue to account for when computing effective coverage would be the issue in compliance with labor regulations. In other words, an effectively covered worker is a wage employee working for an employer complying with EPL. Statistics on such employees can be collected though firm and worker surveys. Some very rare examples of such surveys include the Indonesian Family Life Survey (IFLS) and the National Labour Force Survey (Sakernas), used by Brusentsev et al. (2012) to assess receipt of severance pay among dismissed workers. Restricting the sample to private and public sector employees covered by employment protection legislation and who experienced a job separation, these authors find that two thirds of all eligible employees who separated from a job do not receive their severance payment. Moreover, workers obtain, on average, only $40 \%$ of severance payments due to them; in other words, most of the complying firms are complying only partially. The authors also suggest that compliance and levels of severance pay set by law exhibit sizeable trade-offs. It would be useful to include compliance questions in labor force surveys in order to get a better understanding of EPL compliance, and hence effective EPL coverage, in other countries.

Lastly, a related issue is the extent of informality of employment relationships, as well as a proportion of written versus oral contracts in an economy. For example, in countries such as Guatemala, Morocco, or Cameroun, over $60 \%$ of workers do not have written contracts (ILO, 2016), making it difficult for them to claim any EPL entitlements even if the law in principle provides for them. Thus, the effective EPL coverage would be even lower in these countries, depressing the aggregate role of EPL even further.

At the same time, it would be wrong to compute effective coverage by excluding all informal workers from it. This is because legislation often provides a "lighthouse" effect for workers in informal employment relationships, whereby formal laws set a "social norm" and become a reference for bargaining even among informal waged employees and their employers. ${ }^{8}$ This means that even some informal workers may be covered, both in theory and in practice, by EPL. This means that in countries with non-negligible informal sector, effective coverage would situate somewhere in between the legal coverage and the legal 
coverage that excludes informal workers. Moreover, while employment under oral (often viewed as informal) arrangements is usually considered as offering less stability, in many countries (such as Ireland, Burkina Faso, or Zambia-for some contracts), verbal employment agreements are also legally binding, with the same force as written agreements, and hence, at least in principle, unlawful dismissals may be contested in courts. And conversely, in certain countries, workers under formal written contracts may de facto be deprived of EPL protection: for example, in Russia, it is a common practice to require workers to deposit, at the hiring stage, an application for a voluntary quit which does not contain a specified date, thus rendering Russian employment relations de facto employment at will (Gimpelson et al., 2010). Similar practice has been anecdotally reported in several Eastern European countries. Employers in formal employment relationships may also bypass employment protection legislation by pressuring workers to quit voluntarily and by harassing them (Lepage-Saucier and Wasmer, 2016), negotiate disguised "consent" dismissals, or offer compensation payments below the entitlement levels.

All in all, informality aspect of employment relationships, as well as the unavailability of a written contract, has ambiguous relevance for EPL coverage: they clearly diminish the extent of effective coverage as compared to legal coverage, but the size of this reduction is country-specific and hard to evaluate on a consistent basis. More generally, given the remarks outlined above, it would be fair to conclude that the legal coverage data that we collected represents the highest possible upper bound of EPL coverage, which is substantially higher than the effective coverage that may exist in any given country.

\section{Conclusions}

This study has documented the diversity of legal coverage of employment protection legislation across over 90 countries around 2010. Legal coverage defines those categories of workers and firms that are concerned by the provisions. Coupled with the level of protection afforded to workers and compliance with the EPL provisions, legal coverage helps determine the extent to which regulations actually matter.

By excluding some specific categories of workers or firms, EPL may create labor market segments, the existence of which, in turn, may have diverse social cohesion and distributional effects. Thus, the extent of coverage and definitions of various exclusion conditions have implications for the way EPL reforms should be designed and the effect of EPL and its reforms tested. As suggested by Boeri and Jimeno (2005), "studies not acknowledging the role played by exemptions of small firms may be looking for the "wrong" type of effects." Similar reasoning can be applied to the exemption of workers.

In this paper, we attempted to show that failure to account for EPL coverage in studies looking at the aggregate role of EPL likely leads to an overestimation of the role of EPL. Also, we argued that, because of the rise of new forms of employment, persisting informality, and lack of compliance with regulations in some parts of the world, there are good reasons to believe that the effective, de facto, 
coverage still remains much lower than the legal coverage reported in this paper. Much progress is still to be made to ensure that EPL is a relevant institution.

How can the data documented in this paper be used? Beyond simple visualization of the diversity of EPL coverage, it is hoped that these coverage data will be used to complement the existing EPL measures that reflect the level of protection/strictness of legislation, in studies assessing the potential macroeconomic effects of EPL. It is also hoped that this study will open way to understanding how various exclusions aimed at providing flexibility to some actors in the labor markets actually modify the behavior of these and other actors by modifying the incentives to hire, retain, and fire workers. Such modified behavior may include but not be limited to using alternative employment contracts, inventing new forms of employment, replacing employment contracts by civil contracts, or not recurring to formal contracts altogether. This is an important area for future research.

\section{Endnotes}

${ }^{1}$ For an overview prior to 2010, see Skedinger, 2010. Studies performed on the microlevel are able to account for the fact that EPL rules may not apply to all workers or that different rules may apply to different workers. A prominent example is Boeri and Jimeno, 2005.

${ }^{2}$ ILO, 2015b. Available at: http://www.ilo.org/dyn/eplex/termmain.home.

${ }^{3}$ They include the length of probationary period, substantive and procedural requirements for dismissal, and amount of redundancy and severance pay, as well as options available in case of contesting dismissals.

${ }^{4}$ In fact, a true EPL coverage would take into account all possible EPL regimes in a country and weight them by the proportion of workers concerned by such regimes. For example, if sectoral or industrial collective agreements, contractual agreements, or case law set special regimes for different worker categories, in addition to the general EPL outlined in national legislation, it would be preferable to take them into account. To the extent that existing EPL indicators measuring the level of protection, or costs of dismissals, afforded by EPL (for example, ILO EPLex indicators, or OECD EPL indicators), also reflect mainly laws and general regimes, our coverage data serves as a logical complement to these data.

${ }^{5}$ The relatively standard line of reasoning suggests that the higher is the wedge in the costs associated with terminating a temporary and a permanent worker, the higher is the incidence of temporary employment (Bentolila and Dolado, 1994; Blanchard and Landier, 2002; OECD, 2014).

${ }^{6}$ In this group of countries, the result is partly driven by the USA and the UK, which feature the lowest EPL levels; however, lower correlations remain when we exclude these two countries.

${ }^{7}$ Adopted by International Conference of Labour Statisticians. Available at: http:// www.ilo.org/public/english/bureau/stat/download/res/icse.pdf

${ }^{8}$ The lighthouse effect was first identified in Brazilian setting (Souza and Baltar, 1979), in reference to the use of the minimum wage in wage setting among informally employed workers, but is considered as also applicable to other labor protections. 


\section{Appendix 1}

Table 6 Treatment of excluded categories of workers in constructing coverage

\begin{tabular}{|c|c|c|}
\hline $\begin{array}{l}\text { Excluded categories, as } \\
\text { mentioned in national } \\
\text { law }\end{array}$ & $\begin{array}{l}\text { Included into computations of } \\
\text { coverage of employees and coverage } \\
\text { of employed }\end{array}$ & $\begin{array}{l}\text { For computation purposes, considered as } \\
\text { having at least equal (though possibly superior) } \\
\text { employment protection }\end{array}$ \\
\hline Domestic workers & Yes & No \\
\hline Judiciary & Yes & Yes \\
\hline Seafarers & Yes & No \\
\hline State security corps & Yes & Yes \\
\hline Diplomats & Yes & Yes \\
\hline Mine workers & Yes & No \\
\hline Clergy & Yes & No \\
\hline $\begin{array}{l}\text { Members of political } \\
\text { organizations }\end{array}$ & Yes & Yes \\
\hline UN employees & Yes & Yes \\
\hline Civil/public servants & Yes & Yes \\
\hline Police & Yes & Yes \\
\hline $\begin{array}{l}\text { Managerial/executive } \\
\text { positions }\end{array}$ & Yes & No \\
\hline Sportsmen & Yes & No \\
\hline $\begin{array}{l}\text { Employers' family } \\
\text { members }\end{array}$ & No & - \\
\hline Actors & Yes & No \\
\hline $\begin{array}{l}\text { Auxiliary administrative } \\
\text { employees }\end{array}$ & Yes & No \\
\hline Teachers & Yes & Yes \\
\hline Flying personnel & Yes & No \\
\hline Agricultural workers & Yes & No \\
\hline Army & Yes & Yes \\
\hline $\begin{array}{l}\text { Members of } \\
\text { cooperatives }\end{array}$ & No & - \\
\hline Prison personnel & Yes & Yes \\
\hline Apprentices & Yes & No \\
\hline Journalists & Yes & No \\
\hline $\begin{array}{l}\text { Non-federally regulated } \\
\text { workers }\end{array}$ & Yes & No \\
\hline Dock workers & Yes & No \\
\hline Casual workers & Yes & No \\
\hline Blue-collar workers & Yes & No \\
\hline
\end{tabular}




\section{Appendix 2}

\subsection{Statistical definitions}

According to the Resolution concerning the International Classification of Status in Employment (ICSE - 93), adopted by the ILO Interntaional Conference of Labour Statisticians in 1993,

Employed comprise:

1. Employees, who get a basic remuneration directly dependent on the revenue of the employer-among whom countries may need and be able to distinguish "employees with stable contracts" (including "regular employees")

2. Employers, who hold self-employment jobs (i.e., whose remuneration depends directly on the (expectation of) profits derived from the goods and services produced) and engage one or more person to work for them as "employees," on a continuous basis

3. Own-account workers, who hold self-employment jobs and do not engage "employees" on a continuous basis

4. Members of producers' cooperatives, who hold self-employment jobs in a coperative producing goods and services, where the members take part on an equal footing in making major decisions concerning the cooperative

5. Contributing family workers, who hold self-employment jobs in an establishment operated by a related person, with a too limited degree of involvement in its operation to be considered a partner

6. Workers not classifiable by status, for whom insufficient relevant information is available and/or who cannot be included in any of the preceding categories

Categories 2-5 are considered also as self-employed.

For more information, see:

http://ilo.org/global/statistics-and-databases/statistics-overview-and-topics/status-inemployment/current-guidelines/lang-en/index.htm

Competing interests

The IZA Journal of Labor Policy is committed to the IZA Guiding Principles of Research Integrity. The authors declare that they have observed these principles.

\section{Acknowledgements}

We would like to thank the anonymous referee and the editor for the helpful comments. Responsible editor: Juan Jimeno

We thank, without implicating, Simone Marino for the excellent research assistance; Rip Verkerke, Ben Freyens, Etienne Wasmer, Laura Addati, Theodoor Sparreboom, Mélanie Jeanroy, Valerio De Stefano, and Brandt Wagner for stimulating the discussions; Janine Berg for her continuous support on this project; and the participants of the G-20 working group meeting in Paris for their helpful feedback. The usual disclaimer applies.

Received: 26 November 2015 Accepted: 24 June 2016

Published online: 12 September 2016

References

Adams, Z. and Deakin, S., 2014. Quantitative labour law. Paper presented to the symposium on New Frontiers in Empirical Labour Law Research, Cambridge, 14-15 April 2014

Aleksynska M, Schmidt A (2014) A chronology of employment protection legislation in some selected European countries, ILO Conditions of Work and Employment Series Paper No. 53. ILO, Geneva

Bassanini A, Duval R (2009) Unemployment, institutions, and reform complementarities: re-assessing the aggregate evidence for OECD countries. Oxf Rev Econ Policy 25(1):40-59

Bentolila S, Dolado JJ (1994) Labour flexibility and wages: lessons from Spain. Econ Policy 18:55-99

Bertola, G.; Boeri, T.; Cazes, S. 2000. Employment Protection in Industrialized Countries: The Case for New Indicators, International Labour Review, 139 (1):57-72 
Betcherman G (2012) Labor market institutions. A review of the literature, World Bank Policy Research Working Paper 6276

Betcherman G (2014) Labor market regulations what do we know about their impacts in developing countries? World Bank Policy Research Working Paper 6819

Blanchard O, Landier A (2002) The perverse effects of partial labour market reform: fixed-term contracts in France. Econ J 112(480):F189-213

Blanchard O, Wolfers J (2000) The role of shocks and institutions in the rise of European unemployment: the aggregate evidence. Econ J 110(462):1-33

Boeri T (2011) Institutional reforms and dualism in European labour markets. Handbook of Labour Economics 4(B): $1173-1236$

Boeri T, Jimeno JF (2005) The effects of employment protection: learning from variable enforcement. Eur Econ Rev 49(8):2057-2077

Boeri T, Van Ours J (2008) The economics of imperfect labor markets. Princeton University Press, Princeton

Bouis, R., R. Duval, and F. Murtin (2011) The policy and institutional drivers of economic growth across OECD and nonOECD economies: new evidence from growth regression, OECD Economics Department Working Papers, No. 843, OECD Publishing, OECD: Paris

Brusentsev V, Newhouse D, Vroman W (2012) Severance Pay Compliance in Indonesia, World Bank Policy Research Working Paper 5933

Cacciatore, M., R. Duval and G. Fiori (2012), Short-term pain or gain? A DSGE model-based analysis of the short-term effects of structural reforms in labour and product markets, OECD Economics Department Working Papers, OECD Publishing, OECD: Paris

De Serres, A., F. Murtin, Ch. De La Maisonneuve (2012) Policies to facilitate the return to work. Comp Econ Stud 54:5-42

De Stefano, V., 2016. Casual work beyond casual work in the EU: the underground casualization of the European workforce - and what to do about it. European Labour Law Journal, forthcoming

Deakin S (2014) Labour law and inclusive development, (University of Cambridge) CBR Working Paper No. 458

Deakin S (2015) Labour law and development. Keynote speech at the conference in Cape Town

Gimpelson, V., Kapelyushnikov, R., and A. Lukiyanova (2010) Stuck between surplus and shortage: demand for skills in Russian industry, LABOUR, CEIS, 24(3), pp. 311-332, 09

ILO (2015a) World employment and social outlook: the changing nature of jobs. ILO: Geneva

ILO, 2015b. ILO EPLex Online Database. Available at: http://www.lo.org/dyn/eplex/termmain.home. Accessed: May 2015

ILO (2015c) Employment protection legislation summary indicators in the area of terminating regular contracts (individual dismissals). ILO: Geneva

ILO, 2016 (forthcoming). Non-standard forms of employment: Understanding the challenges, shaping the future. Geneva, ILO

IMF (2016) World economic outlook. IMF, Washington, DC

Lazear E (1990) Job security provisions and employment. Q J Econ 105(3):699-726

Lepage-Saucier, N., and E. Wasmer, 2016. Stress and Employment Protection, A cross-country and cross-province analysis. Journal of Human Capital, Volume 10, Number 1 | Spring 2016, pp. 33-66

Nickell S (1997) Unemployment and labor market rigidities: Europe versus North America. J Econ Perspect 11(3):55-74

Organisation for Economic Co-operation and Development (OECD) (2007) Going for growth. OECD, Paris

Scarpetta S (1996) Assessing the role of labour market policies and institutional settings on unemployment: a cross-country study. OECD Econ Stud 26:43-98

Skedinger P (ed) (2010) Employment protection legislation: evolution, effects, winners and losers. Edward Elgar Publishing, Northampton, MA

Souza P, Baltar P (1979) Salário Mínimo e Taxa de Salários no Brasil. Pesqui Planej Econ 9:629-660

World Bank (2013) The World Development Report 2013: Jobs. WB, Washington, DC

\section{Submit your manuscript to a SpringerOpen ${ }^{\circ}$ journal and benefit from:}

- Convenient online submission

- Rigorous peer review

- Immediate publication on acceptance

- Open access: articles freely available online

- High visibility within the field

Retaining the copyright to your article 